\title{
The Value of Education in Literature and Relevance for Teaching
}

\author{
Suwadi \\ Pendidikan Bahasa dan Sastra Indonesia, Fakultas Pedagogi dan Psikologi, \\ Universitas PGRI Wiranegara Pasuruan, Jawa Timur, Indonesia \\ suwadi.adiansyah@gmail.com
}

\begin{tabular}{ll}
\hline Article History & Received : August $9^{\text {th }} 2021$ \\
& Revision : October $13^{\text {th }} 2021$ \\
& Publication : December $30^{\text {th }} 2021$ \\
\hline
\end{tabular}

\begin{abstract}
This study aims to describe and explain the value of education in literature and how relevant it is for teaching. The method used in this research is descriptive qualitative. Descriptions and explanations lead to circumstances, phenomena and are not limited to data collection but analysis and interpretation of these data. The data collection technique used in this study is a non-interactive technique. Noninteractive data collection techniques by doing intensive reading of the novel and taking notes actively with the method of content analysis. The object of research is literature, namely the Novel Sang Nyai 1 by Budi Sardjono. The approach used by the researcher is an objective approach that emphasizes literature. With this approach, researchers will easily find data as a description related to the value of education and its relevance in teaching. The results showed that the value of education in the literature of Sang Nyai 1 by Budi Sardjono in the form of irrationality, tolerance, and discipline. The irrationality of the characters Kesi and Kang Petruk has a close relationship in instilling educational values through literature. The value of tolerance education shows tolerance for other people and the natural environment. Kang Petruk was assigned by Kiai Sapu Jagad to preserve nature. The value of education in the form of discipline, both personally and socially, is implicitly explained to be interpreted by the reader. The relevance of the value of education in literature for teaching is that literature is the right and good medium to transfer the value of education to students, both at the school and university levels. Through literature, in the novel Sang Nyai 1 by Budi Sardjono, there are educational values in the form of irrationality, tolerance, and discipline. These three educational values are expected to contribute to the teaching of Indonesian at both the school and university levels..
\end{abstract}

Keywords: Educational Value, Literature, Teaching

\section{INTRODUCTION}

In the context of educational values, literature is the crystallization of values contained in society. The educational value in question is the wisdom that is described through literature indirectly about the socio-cultural and life of the people it describes. The socio-cultural influences humans so that they form paradigms, 
actions, beliefs, norms, traditions, and values in society (Daryono Daryono, 2021; Mochamad Bayu Firmansyah, 2021b). The development of literature and society is relatively rhythmic and in tandem which is described through characterizations and characterizations, integrated plots and plots in the story, as well as the meaning of society through action and interaction, roles and positions in social society. Literature is produced for the community which contains themes, plots, experiences and messages to be conveyed to readers. The hope of the author through literature that the reader can interpret and interpret as something that can be useful for his life.

The value of education in literature that reflects people's lives has an important role in realizing an advanced and dignified Indonesian nation (Asih et al., 2017; Daryono, Mochamad Bayu Firmansyah, 2021; Daryono, 2020; Hidayat \& Pendidikan, 2009). However, the challenge of becoming an advanced and dignified Indonesian nation is very big, namely about the value of education. The value of education is reflected through disorientation and waning awareness of the nation's socio-cultural values, the threat of national disintegration, and the weakening of the nation's independence. Because of this, the value of education through literature must be able to provide additional insight so that people become intelligent, strong, independent and have character towards an advanced and dignified Indonesian nation.

The presence of literature (novel) entitled Sang Nyai 1 by Budi Sardjono is expected to contribute to the value of education in the form of wisdom so that readers (society) become intelligent, strong, independent and have character. The novel Sang Nyai 1 by Budi Sardjono tells the story of a journalist named Sam. Sam gets the task of making a romance about the figure of Nyai Roro Kidul. To make the novel, Sam conducted research on the people of Yogyakarta. During his research Sam had spiritual experiences that went against his logic. The novel Sang Nyai 1 by Budi Sardjono is full of wisdom which is reflected in Javanese society. The setting of the Daerah Istimewa Yogyakarta (DIY) has become a symbol of Javanese society and the norms that exist in society become its own wisdom.

Based on the above, the researcher describes and explains the value of education in literature and its relevance for teaching

\section{METHOD}

The method used in this research is descriptive qualitative. This type of research aims to describe and explain various qualitative information carefully and thoroughly (Saputra, 2016; Yusuf A Muri, 2016). Descriptions and explanations lead to circumstances, phenomena and are not limited to data collection but analysis and interpretation of these data. 
The data collection technique used in this study is a non-interactive technique. Non-interactive data collection techniques by doing intensive reading of the novel and taking notes actively with the method of content analysis. Content analysis or content analysis is used to analyze documents so that the contents and meanings contained in the document are known (Kripenorff cit. Ugraheni, 2009).

The object of research is literature, namely the Novel Sang Nyai 1 by Budi Sardjono. The approach used by the researcher is an objective approach that emphasizes literature. With this approach, researchers will easily find data as a description related to the value of education and its relevance in teaching.

\section{RESULTS AND DISCUSSIONS}

\section{The Value of Education in the Novel Sang Nyai 1 by Budi Sardjono}

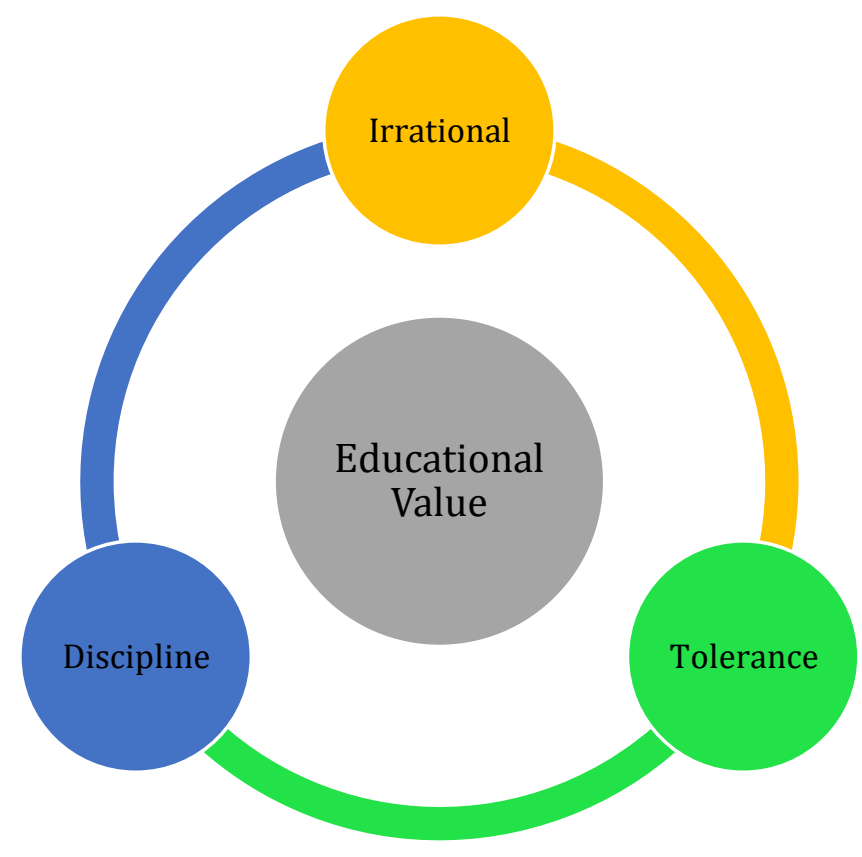

The educational value of the Kesi and Kang Petruk figures is an irrationality which is described through an interconnected whole. Here's the data quote:

(1) “...A moss greens kebaya and brown striped cloth with white stripes, I'm going to the beach for a while, uncle. I'll be here again later." (SY/K:14)

(2) "...the mystery of selo' Gilang, the place where Nyai' Roro Kidul met with Panembahan Senapati?" (SY/K:23)

(3) "..I suspect that Nyai Roro Kidul is stalking where I go. He transformed into a woman named Kesi really? Between yes and no. Yes, because Kesi is always in places reserved for Nyai' Roro 58 Kidul. Parangkusumo. At the sanur beach hotel, at kang petruk's house, on the sanggabuana stage, solo, at a solo star hotel, and maybe at nyai mundingsari's house..." (SY/K: 432) 
(4) “..a house with a strangee and uniqu'e architectural design..” (SY/KP: 96)

(5) "..Day and night my job is to guard the furnace. Don't spill it everywhere. If it overflows, hoooooo..., it's dangerous..." (SY/KP:97)

(6) ".....I was invited to see a- giant stove with flames licking on top of the stove, there is a kind of cauldrons that is no less big. Inside the cauldron, there was a smoldering red liquid, Grandma Petruk, a mysterious figure who was believed to be the guardian of the Merapi crater..." (SY/KP:431)

(7) (7) "He was given the task by Kiai Sapu Jagad to maintain the sustainability and other green plants around Merapi" (SY/KP:7)

(8) "It is said that this is the typical color that Nyai Roro Kidul likes. Therefore, never try to compete when on the beach. The waves could come dragging anyone wearing it to be taken to the middle of the sea. And drowned until death comes!" (SY/NRK:146)

The data (1.SY/K:14) shows the value of irrational education in Kesi figures. Moss green kebaya and brown striated fabric are sacred garments. The irrationality that the author wants to convey is a symbol of sacred clothing when on the south coast and or the surrounding beaches. Kesi is a mysterious and irrational character. The clothes that Kesi wears are sacred and irrational, Nyi Roro Kidul's favorite color. The irrational character of Kesi is also shown in the data (2.SY/K:23). The character of Kesi is described as a person who has the ability to guess or read other people's minds. This ability is not possessed by most people. The depiction of Kesi's character in guessing Sam's mind (main character) mentions a sacred place, namely Selo Gilang (name of place). Selo Gilang is a mysterious place on the south coast, precisely on Parangkusumo beach. This place is a magical meeting place between Nyi Roro Kidul and Panembahan Senopati. Sam (the main character)'s curiosity about Kesi's character has been answered. This is shown in the data (3.SY/K: 432), namely the answers to questions from Sam (the main character) about himself. The meaning of the data is that a woman named Kesi is the incarnation of the figure of Nyi Roro Kidul.

The data (4.SY/KP: 96) shows the strange and irrational state of Kang Petruk's house. The strangeness and irrationality again raise questions to the character Sam (main character) to reveal the real facts. Kang Petruk's character in this literature has an important role in revealing facts that become curious about Sam's character (the main character). The answer to the question of the character Sam (main character) by the author is described in the data (5.SY/KP:97). The author wants to explain the strangeness and irrationality shown through the task of guarding a stove carried out by the character Kang Petruk. The data (6.SY/KP:431) further clarifies the answer that the furnace in question is the crater of Merapi (Mount Merapi). Kang Petruk is the caretaker of the Merapi crater assigned by Nyi Roro Kidul who transformed into a Kesi figure. The irrationality of the characters Kesi and Kang Petruk has a close relationship in instilling educational values through literature. 
The value of education in the form of tolerance is also found in the novel Sang Nyai 1 by Budi Sardjono. Tolerance is an act or attitude that respects differences in ethnicity, religion, ethnicity, opinions, attitudes and actions both towards other people and the natural environment. The value of tolerance education contained in the data (SY/KP:7) shows tolerance for other people and the natural environment. Kang Petruk was assigned by Kiai Sapu Jagad to preserve nature. This task is indicated by the verb "to guard" and tolerance between Kang Petruk and Kiai Sapu Jagad. Kiai Sapu Jagad described in the data quote (SY/KP:7) is a figure who has supernatural powers to maintain sustainability around the slopes of Merapi and has become the trust of the surrounding community. God created nature full of perfection. The task of man is to maintain that perfection. This is shown through the tolerance of Kang Petruk and Kiai Sapu Jagad.

The value of education in the form of discipline is also found in the novel Sang Nyai 1 by Budi Sardjono. Discipline is self-awareness to be able to control oneself and comply with agreed norms or values that apply to oneself and the social environment. The data (SY/NRK:146) shows that Nyai Roro Kidul will be angry if someone wears clothes according to their favorite color. The meaning of the value of education in the form of discipline leads to personal and social. Personal discipline if the self can consciously control and obey the values which in this case is the color of the sacred clothing. The colors of Nyi Roro Kidul's sacred clothes are brown and green. If these values are violated, Nyai Roro Kidul will be angry. Social discipline relates to obeying the rules that apply in social relations in line with the norms in the environment. Through the data (SY/NRK:146) the value of education in the form of discipline both personally and socially is explained implicitly to be interpreted by the reader.

\section{Literature and Relevance for Teaching}

Literature is the right and good medium to transfer the value of education to students, both at the school and university levels (Asih et al., 2017; Mochamad Bayu Firmansyah, 2021a; Mochammad Bayu Firmansyah, 2019; Hidayat \& Pendidikan, 2009; Isnanda, 2015; Sastra, 2017). Through literature, in the novel Sang Nyai 1 by Budi Sardjono, there are educational values in the form of irrationality, tolerance, and discipline. These three educational values are expected to contribute to the teaching of Indonesian at both the school and university levels. The value of education determines the way of life and is influenced by the environment on the person in producing permanent changes in his behavior habits, thoughts and attitudes (Hidayat \& Pendidikan, 2009; Isnanda, 2015; Karsidi, 2017; M, 2007). The value of education determines the way of life and is influenced by the environment on the person in producing permanent changes in his behavior habits, thoughts and attitudes. With the application of the educational value obtained, it is hoped that students will easily interact in the community. 
In the school context, the value of education in Budi Sardjono's Sang Nyai 1 literature is closely related, especially character teaching to students (Asih et al., 2017; Hermawan, 2013; Hidayat \& Pendidikan, 2009; Isnanda, 2015). This can be seen in the value of education in the form of irrationality, tolerance, and discipline. The educational value can be developed for the formation of the character of students. As is the case in the Learning Implementation Plan (RPP). Each character in the novel Sang Nyai 1 by Budi Sardjono conveys its own educational value. Educators must also be able to convey the value of education so that it is easily digested by students. Through literature, it is able to describe people's lives in their time. The stories presented in literature not only present imagination but also present reality and educational values. This is also found in the novel Sang Nyai 1 by Budi Sardjono. This literature presents educational values in the form of irrationality, tolerance, and discipline which is reflected between the southern sea, the palace and Mount Merapi. The value of education has a close relationship with the Javanese tradition of upholding irrationality, tolerance and discipline by paying attention to and placing the southern sea, the palace and Mount Merapi as infinite values. The Javanese tradition in the novel Sang Nyai 1 by Budi Sardjono shows how strong the values that are upheld by the Javanese people are. The following diagram shows the close relationship between Javanese people and the value of education contained in the novel Sang Nyai 1 by Budi Sardjono.

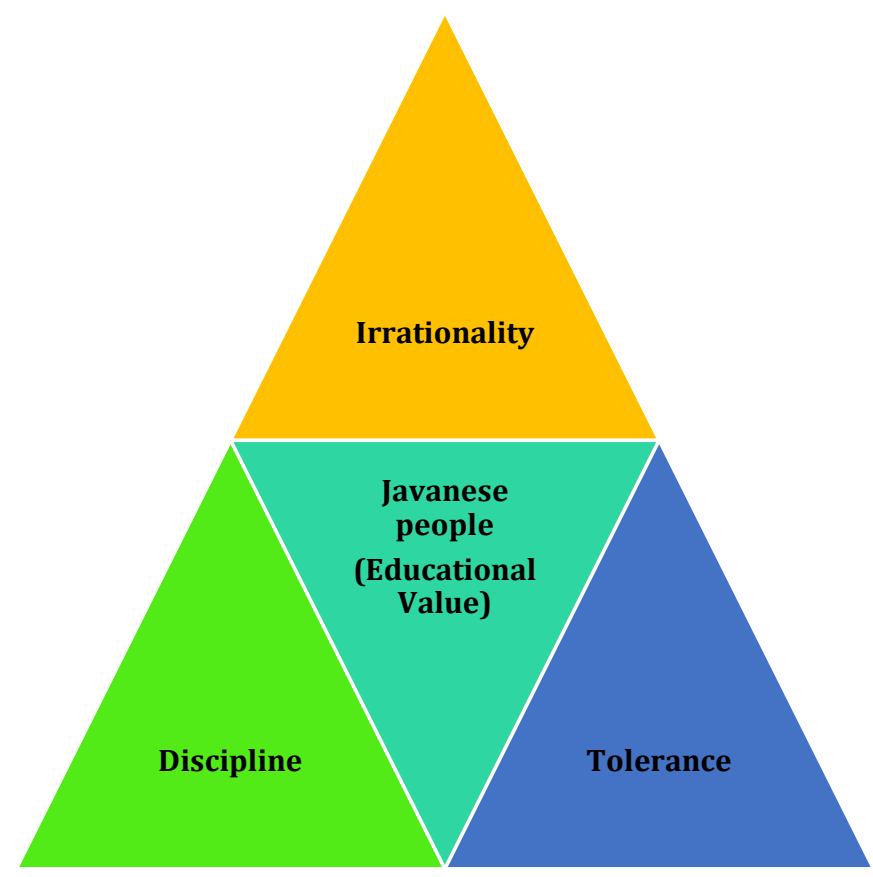

The value of education in the literature of Sang Nyai 1 by Budi Sardjono is relevant to be used as a supporting material for forming the character of students. The formation of the character of these students can be done early in school through 
teaching. Teaching is the process of transferring knowledge by providing educational value so that students have character and can adapt to their environment in the future (Fachruddin et al., 2016; Hidayat \& Pendidikan, 2009; Isnanda, 2015; Karsidi, 2017; Prinata, 2016). The relevance of literature for teaching in schools can be used to improve the ability of students to socialize in society (Dkk 2021 Daryono, 2021; Mochamad Bayu Firmansyah, 2021a; Hidayat \& Pendidikan, 2009; KEMENRISTEKDIKTI, 2018). By teaching the value of education, students will be ready to interact with their environment. In teaching in schools, the educational value contained in the literature can be used as a support for teaching school character nationally.

The Sang Nyai 1 literature by Budi Sardjono is very relevant for teaching literature in universities. This is related to the educational value contained therein. The value of education in the form of irrationality, tolerance and discipline according to the needs of today's students. The content and meaning contained in the novel Sang Nyai 1 by Budi Sardjono contains characters and is very relevant for teaching materials in universities. Through several courses in universities, students can be invited to study and recite in various aspects so that the novel Sang Nyai 1 by Budi Sardjono can be interpreted comprehensively and deeply (Imam Nur Aziz, 2019; Undang-Undang Republik Indonesia Nomor 12 Tahun 2012 Tentang Pendidikan Tinggi, 2012; Rahardjo, 2017; Sudarsana, 2016). Some literature courses have a final standard of ability, namely students are able to categorize types of literature, and study literature in the subjects of literary theory, prose fiction and literary aesthetics.

\section{CONCLUSION}

Based on the results of research and discussion, conclusions are obtained regarding the relevance of educational values in literature for teaching in the novel Sang Nyai 1 by Budi Sardjono. The conclusions will be described below.

The value of education in the literature of Sang Nyai 1 by Budi Sardjono is irrational, tolerant, and disciplined. The irrationality of the characters Kesi and Kang Petruk has a close relationship in instilling educational values through literature. The value of tolerance education shows tolerance for other people and the natural environment. Kang Petruk was assigned by Kiai Sapu Jagad to preserve nature. God created nature full of perfection. The task of man is to maintain that perfection. This is shown through the tolerance of Kang Petruk and Kiai Sapu Jagad. The value of education in the form of discipline, both personally and socially, is implicitly explained to be interpreted by the reader. Discipline is self-awareness to be able to control oneself and comply with agreed norms or values that apply to oneself and the social environment.

The relevance of the value of education in literature for teaching is concluded as follows. Literature is the right and good medium to transfer the value of education 
to students, both at the school and university levels. Through literature, in the novel Sang Nyai 1 by Budi Sardjono, there are educational values in the form of irrationality, tolerance, and discipline. These three educational values are expected to contribute to the teaching of Indonesian at both the school and university levels. The value of education determines the way of life and is influenced by the environment on the person in producing permanent changes in his behavior habits, thoughts and attitudes. In the school context, the value of education in the literature of Sang Nyai 1 by Budi Sardjono is closely related, especially teaching character to students. Sang Nyai 1 literature by Budi Sardjono is very relevant for teaching literature in universities. This is related to the educational value contained therein. The value of education in the form of irrationality, tolerance and discipline according to the needs of today's students. The content and meaning contained in the novel Sang Nyai 1 by Budi Sardjono contains characters and is very relevant for teaching materials in universities. Through several courses in universities, students can be invited to study and recite in various aspects so that the novel Sang Nyai 1 by Budi Sardjono can be interpreted comprehensively and deeply.

\section{REFERENCES}

Asih, A., Tantri, S., \& Ganesha, U. P. (2017). NILAI-NILAI PENDIDIKAN KARAKTER DALAM NOVEL TANTRI ( PEREMPUAN YANG BERCERITA ) KARYA COK DI SEKOLAH DASAR. Proceedings Education and Language International Conference, 1(1), 57-68.

Daryono, Mochamad Bayu Firmansyah, D. (2021). Landasan Pendidikan:Teori dan Aplikasi dalam Aspek Humas Pendidikan di Indonesia (1st ed.). Ari Institute.

Daryono. (2020). Menuju Manajemen berbasis Sekolah (M. Z. A. A. I. S.M (ed.); 1st ed.). Lembaga Academic \& Research Institute.

Daryono, Daryono. (2021). Zoning System In Education Application In The City Of Pasuruan, East Java. EDUTEC : Journal of Education And Technology, 4(3), 450459. https://doi.org/10.29062/edu.v4i3.100

Daryono, Dkk 2021. (2021). Society 5.0 Fostering Spirituality and Humanity. In P. . Prof. Akhsanul In'am (Ed.), Proceedings Of International Seminar Society 5.0 Fostering Spirituality and Humanity (p. 275). Postgraduate University of Muhammadiyah Malang, Indonesia.

Fachruddin, S., Cokroaminoto, U., \& Fachruddin, S. (2016). Pendidikan Pembelajaran Pendidikan Lingkungan Hidup (Issue January).

Firmansyah, Mochamad Bayu. (2021a). MULTIMODALITAS MODEL PEMBELAJARAN PSIKOLOGI SASTRA (T. D. P. Khatulistiwa (ed.); 2021st ed.). Delta Pijar Khatulistiwa.

Firmansyah, Mochamad Bayu. (2021b). The Effectiveness Of Multimodal Approaches In Learning. Journal of Education And Technology, 4(3), 469-479.

Firmansyah, Mochammad Bayu. (2019). Literasi Multimodal Bermuatan Kearifan Lokal. 10(July), 60-68.

Hermawan, B. (2013). Multimodality: Menafsir Verbal. Bahasa \& Sastra, 13 No. 1 A. 
Hidayat, A., \& Pendidikan, I. (2009). Pembelajaran Sastra di Sekolah. 14(2), 1-7. Imam Nur Aziz. (2019). PEMERATAAN AKSES PENDIDIKAN BAGI MASYARAKAT INDONESIA. Researchgate, 12(3), 14.

Isnanda, R. (2015). PERAN PENGAJARAN SASTRA DAN BUDAYA DALAM PEMBENTUKAN KARATER SISWA SEKOLAH DASAR. 2(2), 174-182.

Karsidi, R. (2017). Budaya lokal dalam liberalisasi pendidikan. 1(2), 19-34. https://doi.org/10.26740/jsm.v1n2.p19-34

KEMENRISTEKDIKTI. (2018). Menteri Nasir: Indonesia Sambut Revolusi Industri ke-4 dalam Forum Pendidikan Dunia 2018. KEMENRISTEKDIKTI, 3.

M, A. I. A. (2007). Pembelajaran sastra multikultural di sekolah: aplikasi novel. 19(1), 60-75.

Undang-Undang Republik Indonesia Nomor 12 Tahun 2012 Tentang Pendidikan Tinggi, (2012).

Prinata, S. P. (2016). SYAIR TEMBANG TARI KIPRAH GLIPANG MASYARAKAT MADURA KABUPATEN PROBOLINGGO. universitas jember.

Rahardjo, M. (2017). Studi kasus dalam penelitian kualitatif: konsep dan prosedurnya.

Saputra, S. (2016). Pengaruh Model Pembelajaran Discovery Learning Berbasis Lingkungan Sekolah Terhadap Hasil Belajar Siswa Pada Materi Keanekaragaman Hayati. Jesbio, V(2), 34-39.

Sastra, P. P. (2017). Journal Indonesian Language Education and Literature. 2(2), 163-179.

Sudarsana, I. K. (2016). Pemikiran Tokoh Pendidikan Dalam Buku Lifelong Learning: POLICIES, PRACTICES, AND PROGRAMS (Perspektif Peningkatan Mutu Pendidikan di Indonesia). Jurnal Penjaminan Mutu, 2, 44-53. https://doi.org/10.25078/jpm.v2i2.71

Yusuf A Muri. (2016). Metode Penelitian Kuantitatif, Kualitatif \& Penelitian Gabungan. PRENADAMEDIA GROUP. 